\title{
1P1-D29
}

\section{物質の相変化を利用した浮力調整装置の開発 \\ 一金属ベローズを用いた内部搭載型浮力調整装置の開発一}

\section{Development of a Buoyancy Control Device}

Utilizing Phase Change of Material

- Development of a Buoyancy Control Device within a Robot Body Utilizing Metallic Bellows -

学 井出口宏徳 (龍谷大) 学 吉井 星（龍谷大）
正 泚谷 恒司 (龍谷大)

Hironori IDEGUCHI, Ryukoku University, Sho YOSHII, Ryukoku University Koji SHIBUYA, Ryukoku University

\begin{abstract}
The final goal of this study is to develop a buoyancy control device for underwater robots utilizing phase change of material. A conventional underwater robot and a conventional submarine adjust buoyancy by discarding a set of iron balls or seawater in other place, which is harmful to the environment. Therefore, we proposed new buoyancy control method utilizing phase change of material. Our previous method for inducing volume change use rubber for changing the volume, but rubber is not so strong. Therefore, we developed a new buoyancy control device using metallic bellows. The control part of the device is within a robot body to prevent it from suffered from water. As a result of experiments, we confirmed that the durability of the device was improved without suffering heat and cooling ability.
\end{abstract}

Key Words: underwater robot, buoyancy control, Metallic bellows

\section{1. 緒言}

現在、一般に使用されている潜水能ノを有する機械には、 金属塊をおもりとして潜航し、そのおもりを投亲することに より浮上する方式や、厈縮空気を使用してタンクに海水を注 人・排出することによって潜水する方式がとられている。し かし、これらの方式では、海中への物質の投亲や他海域への 海水排出といった環境破壊の原因となる問題が生じる。そこ で、外部と物質のやり取りを行わない浮力調整方式が必要と なる。

本研究では、物質の相変化による体積変化を利用した浮」 調整装置の開発を行っている。これまでの研究では、体積変 化物質にパラフィンワックスやラードを使用し、ゴム膜や金 属製ピストンを介して体積変化を外部へ伝達した[1]-[5]。しか し、ゴム膜の劣化や金属ピストンの摩擦によるエネルギー損 头という問題が生じたため、装置を新しく製作した。本報告 では、金属ベローズを用いた体積伝達機構と浮う㸡整時を機 体内部に搭載した時の浮力詄整について述べる。

\section{2. 浮力調整装置・機体の概要}

\section{1 原理}

今回の浮ノ㸡整装置は、体積変化の伝達に企属ベローズの 伸縮を利用する。体積変化物質には、パラフィンワックスを 使用し、その加熱・冷却にはペルチェ素子を用いる。

\section{2 装置制作}

製作した装置の概略図を図 1 に小寸。装置上部はアルミニ ウムを用いて製作し、図2のようにペルチェ素子設置用の溝 を加工した。ベローズの伸縮部分には、断熱のため水を封人 した。

\section{3 機体製作}

浮ノ詄整装置の浮ノ実験のために実験用ロボット機体を 製作した。機体の概略汹を図 3 に小寸。機体は亡にアクリル を用い、機体上面のみベルチェ素子の放熱用にアルミ板を使 用して製作した。

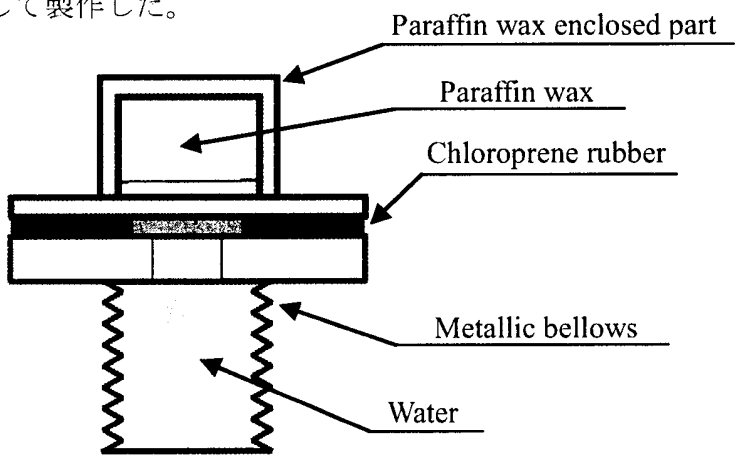

Fig. 1 Schematic diagram of buoyancy control device

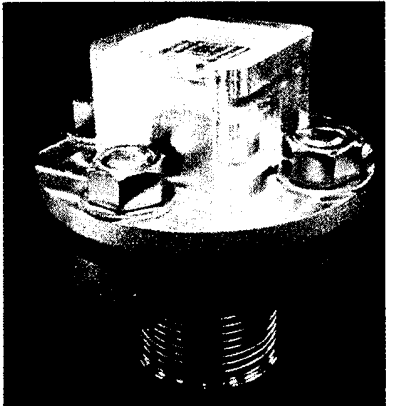

Fig. 2 Photograph of buoyancy control device 


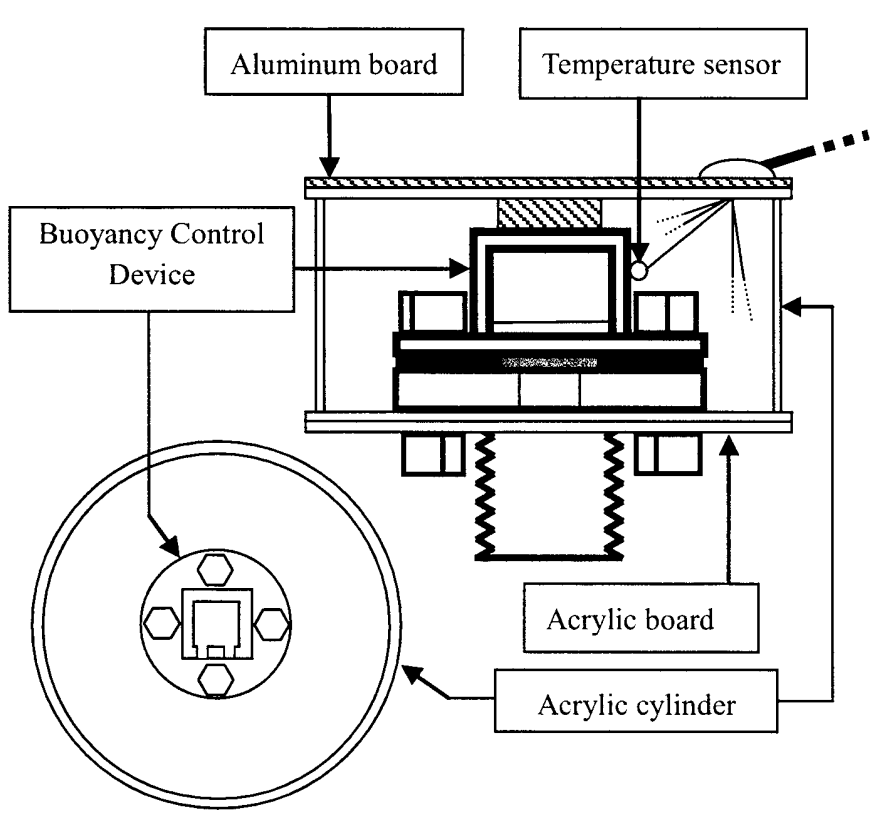

Fig.3 Schematic diagram of prototype robot

\section{3. 実験}

\section{1 稼働実験}

室内におうい、水平な台の上に載せた浮ノ調整装置単体を ペルチェ素子により加熱し、その時のベローズ伸縮部分伸び をポテンショメータにより測定した。

ベローズの伸縮量とベローズ伸縮部分の内柊・外烽を基に 算出した予想浮力変化と、封人したパラフィン量から算出し た最大浮力変化量を図 4 に亦寸。このグラフから、金属べロ ーズにより体積伝達を行うことが十分に可能であることが 分かる。

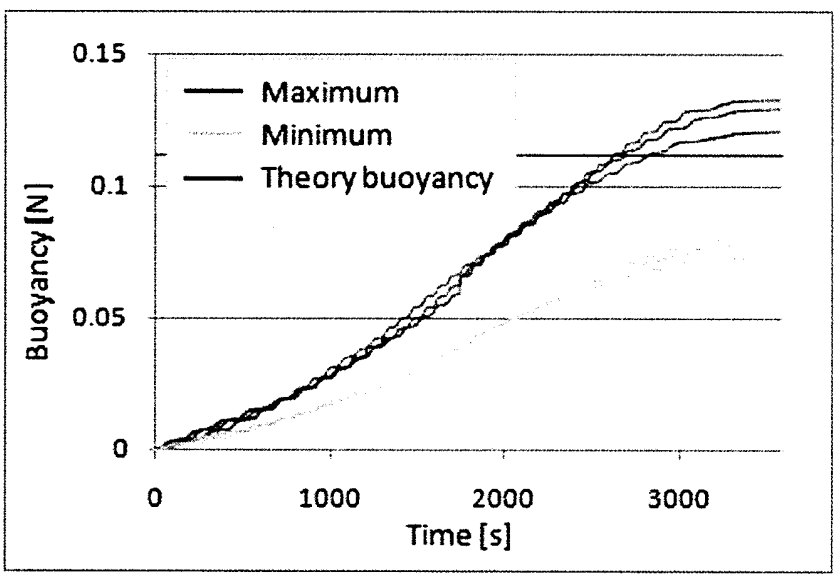

Fig. 4 Expectation buoyancy from amount of expansion

\section{2 浮力調整実験 I}

浮ノ䏒整装置を搭載した機体をワイヤに取り付け、機体上 部のアルミ板上に重りを載せて水中に沈めた。ひずみゲージ を取り付けたステンレス板（晾さ $3 \mathrm{~mm}$ ) に、先ほどのワイヤ を取り付けた。このひずみゲージにより浮ノ変化を測定した。 また、四 3 に示寸们置に設置した温度センサで浮調整装置 上部の側自温度を測定した。なお、各測定のサンプリング楇 波数は $1 \mathrm{~Hz}$ である。

浮小変化量と温度データを眓 5 に亦す。このグラフから、
浮ノ増加を十分に得られる事が分かる。しかし、浮うを減少 させる過程では、常温付近の温度において浮乃が完全に元に 扊っていないことがわかる。初期浮力まで戻すには長い時問 を要することが少されれる。

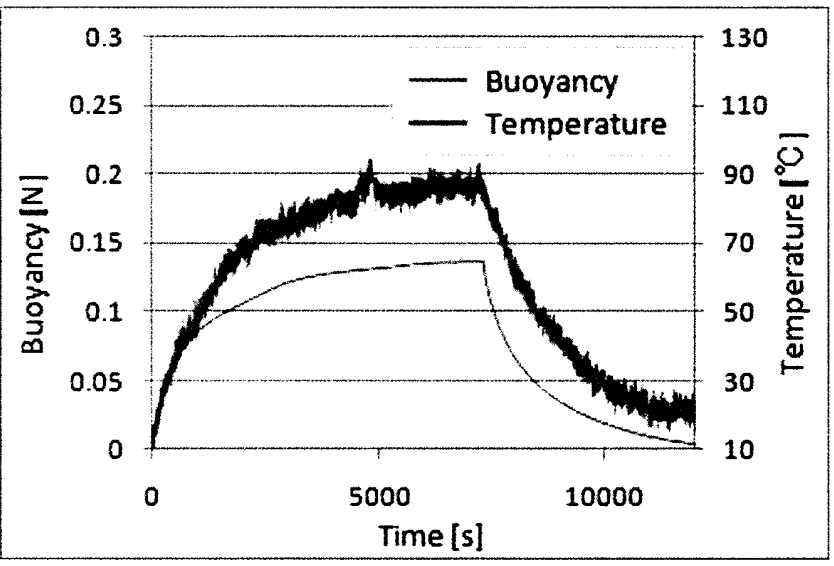

Fig.5 Amount of buoyancy change and temperature

\section{3 冷却実験 II}

3.2 と同様に機体をひずみゲージを取り付けたステンレス 板に吊るした状態で水中にしずめ、20 分每に加熱・泠却を切 り替えて浮ノ変化量と温度を測定した。冷却方法はペルチェ 素子を使用するもの（ム）と、ペルチェ素子を使用せずに自 然冷却のみのもの（B）、2 種類の条件で測定を行った。

浮力変化量と温度のデータを図 6 に小寸。このグラフから、 常温近辺を除きベルチェ素子の冷却利用による、浮ノ夙整效 果はないことが分かる。

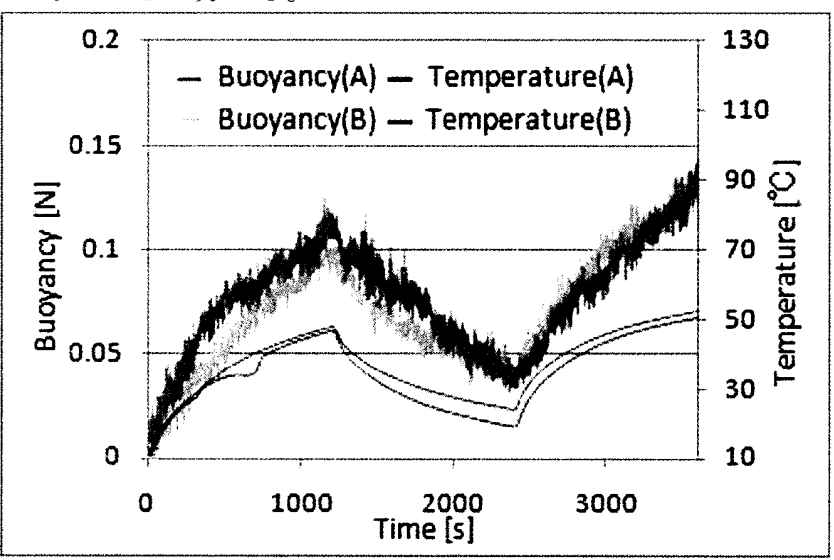

Fig.6 Cooling effect of peltier device

\section{4 装置単体との比較}

シーリング剤と断熱シートにより防水を施した浮う佩整 装置単体にワイヤと取り付け、ひずみゲージを取り付けたス テンレス板（厚さ $3 \mathrm{~mm}$ ）に吊るした状態で水中に沈め、ペル チェ素子により 20 分每に加熱・冷却・加熱を行い、浮方変 化量を測定した。

この浮う変化量と機体に搭載した場命の浮力変化量を比 較したグラフを図 7 に亦寸。このグラフから、内部搭載した 浮ノ調整装置の方が容易に大きな浮ノ変化を得られること が分かる。また、冷却時の浮ノ減少量を比䡛しても内部搭載 型が劣っているわけではないので、浮ノ夙整装置を内部搭載 する事で、加熱時には大きな断熱性を得て、冷却時には変わ ら好放熱性を保つことが出米たと考えられる。 


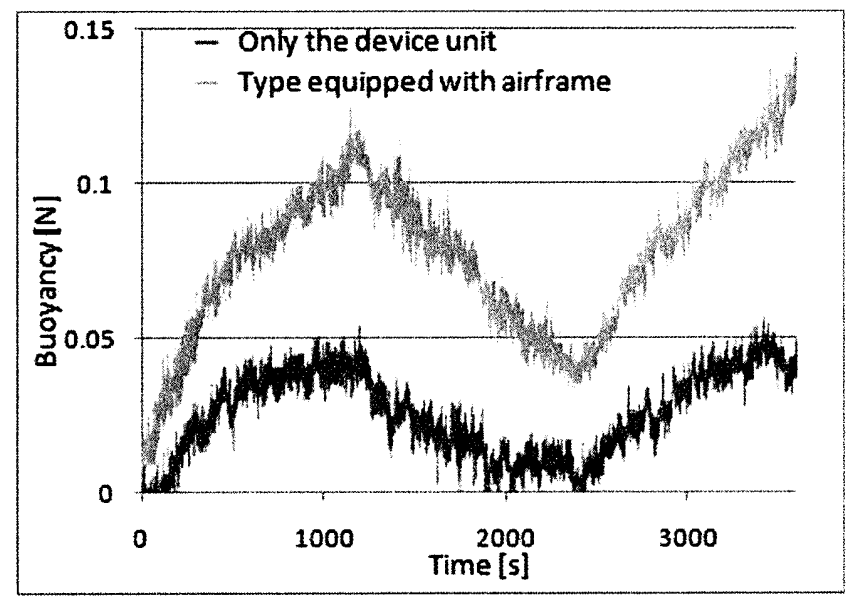

Fig. 7 Comparison of device and prototype robot

\section{4. 結言}

体積伝達機構に金属ベローズを使用する事で、耐久性が问 上した。機体内部に浮力調整装置を搭載する事で、冷却時の 放熱性を損なうことなく、加熱時の断熱性を向上できた。浮 力調整装置内部に電子機器を封人しないことで保守性・メン テナンス性が问上した。

課題としては、より效率の良い放熱・断熱を行える機体と 浮力調整装置の設置方法の検討、装置の柽量化、内部電源を 搭載した遠隔操作可能なロボットの開発などが举げられる。

\section{文 献}

[1]. Koji Shibuya, Yuichi Kado, Suguru Honda, Taro Iwamoto and Kazuyoshi Tsutsumi, "Underwater Robot with a Buoyancy Control System Based on the spermaceti Oil Hypothesis," Proc. Of 2006 IEEE/RSJ International Conference on Intelligent Robots and Systems(IROS2006),(2006.10)

[2]。絘谷㑑司，門裕一，本田卓，岩本太郎，堤一義，マッコウクジ ラの脑油伋説に基づく浮力調整装置を有寸る水中ロボットの 試作，日本機械学会ロボティクス・メカトロニクス满演 会' 06 (ROBOYECH' 06)，1P1-E31，(2006.5)

[3]. 滥谷怕司, 門裕一, 本田卓, 岩本太郎, 堤一義, マッコウクジ 今の脳油説に基べく浮力調整装置を用いた水中ロボットの姿 勢制御, 第2 1 回H本ロボット学会学術諢演会, 3A26, (2006.9)

[1]. 滥谷恒司, 河合光太, 吉沺晃浩, 物質の相変化を利用した浮 力調整装置の開発, 日本機械学全ロボティクス・メカトロニ クス譜演会' 07 (ROBOVECH' 07)

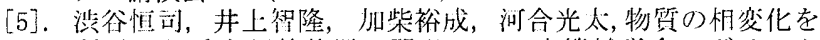
利用した浮力調整装置り開発, 日本機械学会ロボティク ス・メカトロニクス满演侌' 08(ROBOMECH' 08) 